\title{
Genistein inhibits tumor invasion by suppressing multiple signal transduction pathways in human hepatocellular carcinoma cells
}

\author{
Shulhn-Der Wang ${ }^{5+}$, Bor-Chyuan Chen², Shung-Te Kao ${ }^{3,4+}$, Ching-Ju Liu ${ }^{2}$ and Chia-Chou Yeh ${ }^{1,2^{*}}$
}

\begin{abstract}
Background: Genistein (Gen) exhibits anti-mutagenic and anti-metastatic activities in hepatoma cell lines. Gen has suppressive effects on tumor growth and angiogenesis in nude mice. Gen suppresses the enzymatic activity of matrix metalloproteinase (MMP)-9; however, the mechanism underlying its anti-invasive activity on hepatocellular carcinoma (HCC) cells is unclear.

Methods: In this study, the possible mechanisms underlying Gen-mediated reduction of 12-O-Tetradecanoylphorbol13-acetate (TPA)-induced cell invasion and inhibition of secreted and cytosolic MMP-9 production in human hepatoma cells (HepG2, Huh-7, and HA22T) and murine embryonic liver cells (BNL CL2) were investigated.

Results: Gen suppressed MMP-9 transcription by inhibiting activator protein (AP)-1 and nuclear factor-K B (NF-kB) activity. Gen suppressed TPA-induced AP-1 activity through inhibitory phosphorylation of extracellular signal-related kinase (ERK) and c-Jun N-terminal kinase (JNK) signaling pathways, and TPA-stimulated inhibition of NF-KB nuclear translocation through IKB inhibitory signaling pathways. Moreover, Gen suppressed TPA-induced activation of ERK phosphatidylinositol 3-kinase/Akt upstream of NF-KB and AP-1.
\end{abstract}

Conclusions: Gen and its inhibition of multiple signal transduction pathways can control the invasiveness and metastatic potential of HCC.

Keywords: Genistein, TPA, Matrix metalloproteinase 9, Tumor invasion, Nuclear factor-kB, Activator protein 1

\section{Background}

Hepatocellular carcinoma (HCC) is the fifth most common cancer and the third most frequent cause of cancerrelated mortality worldwide, with 6,000,000 new cases diagnosed annually [1,2]. HCC is prevalent in Sub-Saharan Africa and Southeast Asia, including Taiwan. HCC is associated with various risk factors, including chronic infection with hepatitis B or C viruses, environmental carcinogens, chronic alcohol abuse, and non-alcoholic fatty liver disease $[2,3]$. HCC is a hypervascular tumor, commonly involving venous invasion, and HCC often progresses to intra- and

\footnotetext{
* Correspondence: yehcc0530@gmail.com

${ }^{\dagger}$ Equal contributors

'School of Post-Baccalaureate Chinese Medicine, Tzu Chi University, Hualien, Taiwan

2Department of Chinese Medicine, Buddhist Dalin Tzu Chi General Hospital, 2 Min-Sheng Road, Dalin Town, Chia-Yi 62247, Taiwan

Full list of author information is available at the end of the article
}

extra-hepatic metastases [4]. Invasion and metastasis of cancer cells are the primary causes of cancer deaths, which are complicated processes involving proteolytic enzymes that participate in the degradation of environmental barriers such as the extracellular matrix and basement membrane. Among these enzymes, the matrix metalloproteinases (MMPs), which comprise a family of zincdependent endopeptidases, are intimately involved in the invasion and metastasis of various tumor cells $[5,6]$. The MMP family is involved in extracellular matrix degradation and is also associated with malignancy and metastasis. The $M M P-9$ gene is strongly expressed in invasive HCC [7], and the MMP-9 protein content in HCC is greater than in the surrounding liver parenchyma. Therefore, MMP-9 may be used as a marker for the invasiveness and metastatic potential of HCC [7]. The activity of MMP9 is tightly controlled, with regulation occurring primarily at the transcriptional level [5]. The $M M P-9$ promoter is 
highly conserved and contains multiple functional elements, including nuclear factor- $\mathrm{kB}(\mathrm{NF}-\mathrm{kB})$ and activator protein (AP)-1 elements [8-10].

12-O-Tetradecanoylphorbol-13-acetate (TPA) is one of the most widely used agents for studying the mechanisms of carcinogenesis [11]. TPA exhibits numerous biological effects by altering gene expression, a process that involves activation of protein kinase C (PKC) [12]. In addition to carcinogenesis, TPA induces MMP-9 expression via PKC-dependent activation of the Ras/extracellular signalregulated protein kinase (ERK) signaling pathway, thus increasing the invasiveness of cell lines [13]. Previous reports have demonstrated that TPA-activated NF- $\mathrm{KB}$ and AP-1 activities, and increased MMP-9 expression in response to NF- $\mathrm{kB}$ activation, are associated with tumor metastasis [14].

Genistein (Gen; 5,7,4' -trihydroxyisoflavone), a soybeanderived isoflavone, has been identified as a potential cause for the low incidence of certain types of tumors, such as lung [15], breast, gastric, colon, and prostate cancers, and HCC $[9,15-19]$. Gen is also a principal chemopreventive component of soy and exerts a wide array of chemopreventive activities in each stage of multistep carcinogenesis $[20,21]$. Previous studies [20,22] showed that Gen is a promising agent for inhibiting the metastatic potential of HCC. Gen may affect HCC progression as a result of its effects on cell cycle progression and apoptosis [16,22]; however, there are no reports on the mechanism of the inhibitory effects of Gen on TPA-induced invasion and MMP-9 expression. Herein, we demonstrate that the suppression of TPA-induced MMP-9 activity by Gen occurs via disruption of NF- $\mathrm{KB}$ and AP-1 signaling pathways in HepG2 cells.

\section{Methods \\ Reagents}

Genistein (Sigma Chemical Co., St. Louis, MO, USA) was dissolved in $0.1 \mathrm{M} \mathrm{Na}_{2} \mathrm{CO}_{3}$ to create a $10-\mathrm{mM}$ stock solution. TPA (Sigma-Aldrich, St. Louis, MO) was prepared in phosphate-buffered saline (PBS; $137 \mathrm{mM} \mathrm{NaCl}, 1.4 \mathrm{mM}$ KH2PO4, 4.3 mM Na2HPO4, $2.7 \mathrm{mM} \mathrm{KCl,} \mathrm{pH} \mathrm{7.2).} \mathrm{For}$ analysis of the signaling pathways involved in TPA-induced DNA-binding of AP-1 and NF- $\mathrm{kB}$, we also treated HepG2 cells with the p38 inhibitor SB203580 (SB), the MEK/ERK inhibitor PD98059 (PD), the JNK inhibitor JNKI, the IKK inhibitor BMS (AKTI), LY294002 (LY, an Akt inhibitor) and bisindolylmaleimide (GF, GF109203X, a PKC inhibitor) were purchased from Sigma-Aldrich to block these pathways.

\section{Cell culture and TPA treatment}

Human hepatoma cell lines (HepG2, Huh-7, and HA22T) and murine embryonic liver cells (BNL CL2) were maintained in Dulbecco's modified Eagle medium (DMEM; Life
Technologies, Gaithersburg, MD, USA) and supplemented with $10 \%$ fetal bovine serum (FBS; HyClone, Logan, UT, USA). The cells were transiently transfected with $5 \mu \mathrm{g}$ of plasmid DNA using SuperFect transfection reagent (Qiagen, Valencia, CA, USA). TPA (Sigma-Aldrich) was

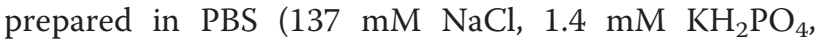
$4.3 \mathrm{mM} \mathrm{Na}_{2} \mathrm{HPO}_{4}$, and $2.7 \mathrm{mM} \mathrm{KCl}, \mathrm{pH} \mathrm{7.2).} \mathrm{HepG2,}$ Huh-7, HA22T, and BNL CL2 cells were cultured in $25-\mathrm{cm}^{2}$ flasks at $37^{\circ} \mathrm{C}$. The flasks were immediately capped and sealed with parafilm to minimize evaporation. Cell growth was measured using a modified 3-(4,5-dimethylthiazol-2-yl)-2,5-diphenyltetrazolium bromide (MTT) assay. HepG2 cells were resuspended with $100 \mu \mathrm{L}$ in 96-well plates and cultured with or without $80 \mu \mathrm{M}$ TPA and Gen, incubated for $24 \mathrm{~h}$, then $20 \mu \mathrm{L}$ MTT was added to each well and incubated at $37^{\circ} \mathrm{C}$ for $4 \mathrm{~h}$. The supernatant was removed, $200 \mu \mathrm{L}$ dimethyl sulfoxide (DMSO) was added to each well to solubilize the formazan product, and the absorbance was measured at $470 \mathrm{~nm}$ using a microplate reader (Sigma).

\section{Wound healing assay}

Hepatoma cell lines were grown to $90 \%$ confluence in a 6-well plate at $37^{\circ} \mathrm{C}$ in a $5 \% \mathrm{CO}_{2}$ incubator. A wound was created by scratching cells with a sterile $200 \mu \mathrm{L}$ pipette tip, then the cells were washed twice with PBS to remove floating cells and added to serum-free medium. Photos of the wound were obtained via microscopy under $100 \times$ magnification.

\section{Invasion assay}

Cell invasion was assessed using Matrigel-coated film inserts $(8-\mu \mathrm{m}$ pore size) fit into 24-well invasion chambers (Becton-Dickinson Bioscience, Franklin Lakes, NJ, USA). HepG2 cells $\left(5 \times 10^{4}\right)$ were suspended in $200 \mu \mathrm{L}$ of DMEM and added to the upper compartment of an invasion chamber in the presence or absence of $80 \mu \mathrm{M}$ TPA; DMEM $(500 \mu \mathrm{L})$ was added to the lower chamber. The chambers were incubated at $37^{\circ} \mathrm{C}$ in a $5 \% \mathrm{CO}_{2}$ atmosphere. The filter inserts were removed after a 24-h incubation period, and cells on the upper surfaces of the filters were removed with cotton swabs. Cells on the lower surfaces of the filters were stained with crystal violet, and the number of cells was determined with the use of a microscope. Final values were calculated as the mean of the total number of cells from 3 filters.

\section{Zymography}

Gelatin zymography was used for determination of expression and activities of MMP-9 in TPA-treated (with or without Gen) human HepG2 cells. HepG2 cells were seeded in 100 -mm plates using serum-free medium and pretreated with TPA and different concentrations of Gen. After incubation for $24 \mathrm{~h}$, the conditioned media were collected and 
quantification of the protein concentrations was performed using the Bio-Rad protein assay (Bio-Rad Laboratories, Inc., Hercules, CA, USA). Culture supernatants were subjected to electrophoresis on gelatin substrate gels (10\% sodium dodoecyl sulfate [SDS]-polyacrylamide gels containing $1 \mathrm{mg} / \mathrm{mL}$ gelatin). Subsequently, the gels were treated with $2.5 \%$ Triton $\mathrm{X}-100$ for $30 \mathrm{~min}$, followed by incubation for $24 \mathrm{~h}$ at $37^{\circ} \mathrm{C}$ in a buffer containing $100 \mathrm{mM}$ Tris-HCl, $\mathrm{pH} 7.4,0.15 \mathrm{M} \mathrm{NaCl}$, and $15 \mathrm{mM} \mathrm{CaCl}_{2}$. The gels were stained with Coomassie Blue R-250 and then destained with water until emergence of clear zones that indicated proteolytic activity against a blue background.

\section{Luciferase assay}

Wild-type sequences were obtained for $N F-\kappa B$ (GGAA TTCCCC) and AP-1 (TGAGTCA) sites. Reporter plasmids (pNF-kB-Luc and pAP-1-Luc) were purchased from Stratagene (La Jolla, CA, USA). Plasmid DNAs were prepared with a Qiagen Plasmid Midi Kit (Qiagen). The $M M P$-9-Luc plasmid was kindly provided by Dr. C.K. Glass [23]. Hepatoma cell lines were treated with $80 \mu \mathrm{M}$ TPA for $8 \mathrm{~h}$, and luciferase activity was determined as previously described [14]. Briefly, HepG2 cells in each well were washed with PBS and at lysed with $50 \mu \mathrm{L}$ of passive lysis buffer (Promega, Madison, WI, USA) at various time points after treatment. Lysates were transferred to 96-well white plates and substrate was added (Promega) to assess the luciferase activity with a microplate reader (Synergy HT, Bio-Tek, Winooski, VT, USA). Relative luciferase activity was calculated by dividing relative luciferase units of $M M P-9, N F-\kappa B$, or $A P-1$ reporter plasmidtransfected cells by the relative luciferase units of pGL3basic-transfected cells.

\section{Preparation of nuclear extracts and electrophoretic mobility shift assay}

HepG2 cells were treated with $80 \mu \mathrm{M}$ TPA and 10-40 $\mu \mathrm{M}$ Gen. Nuclear extracts were prepared as described previously [24]. Briefly, cells were stimulated, harvested by centrifugation, washed twice with cold PBS, and then nuclear extracts were prepared using NE-PER reagent (Pierce, Rockford, IL, USA), according to the manufacturer's instructions. Biotin-labeled complementary oligonucleotides corresponding to $N F-\kappa B$ and $A P-1$ binding sites were annealed. Biotinylated electrophoretic mobility shift assays (EMSAs) were performed as previously described [8], and gels were transferred to nylon membranes after electrophoresis. Membranes were blocked in solution and detected with alkaline phosphatase-conjugated streptavidin (Chemicon, Australia) followed by chemiluminescence (Roche, Germany).

\section{Western blot analysis}

Hepatoma cells were treated with $80 \mu \mathrm{M}$ TPA and 10-40 $\mu \mathrm{M}$ Gen and lysed in $250 \mu \mathrm{L}$ of sample buffer (62.5 mM Tris-HCl, 2\% SDS, 10\% glycerol, $50 \mathrm{mM}$ dithiothreitol, and $0.1 \%$ bromophenol blue, $\mathrm{pH}$ 6.8). We also collected the supernatants from cultures treated with $80 \mu \mathrm{M}$ TPA and Gen. The supernatants were concentrated 40-fold with a Minicon filter (Millipore, Billerica, MA, USA) with a $15-\mathrm{kDa}$ cutoff pore diameter. Protein concentrations were determined with a BCA Protein Assay Kit (Pierce, Rockford, IL, USA). To investigate the different cell fractions, the cells were scraped into $2 \mathrm{~mL}$ of buffer $\mathrm{A}$ (20 mmol/L Tris $\mathrm{HCl}, \mathrm{pH} 7.5,0.25 \mathrm{~mol} / \mathrm{L}$ sucrose, $10 \mathrm{mmol} / \mathrm{L}$ EGTA, $2 \mathrm{mmol} / \mathrm{L}$ EDTA, $20 \mu \mathrm{g} / \mathrm{mL}$ leupeptin, $10 \mu \mathrm{g} / \mathrm{mL}$ aprotinin, and $200 \mu \mathrm{mol} / \mathrm{L}$ phenylsulfonyl fluoride) at $4^{\circ} \mathrm{C}$ and were sonicated and separated into cytosolic fraction and membrane fraction as described previously [25]. The cytoplasmic extracts (cytosol) were prepared using Cytoplasmic Extraction Reagent (Pierce), according to the manufacturer's instructions. For translocation of p65, the protein concentrations of p65 in cytoplasmic extracts and nuclear extracts were detected by western blotting. Proteins $(10 \mu \mathrm{g}$ for cell lysates; $40 \mu \mathrm{g}$ for supernatants) were separated using 10\% SDS-polyacrylamide gel electrophoresis, and protein bands were transferred electrophoretically to nitrocellulose membranes. Membranes were probed with polyclonal antibodies against p65, MMP9, epidermal growth factor receptor (EGFR), PKC $\alpha, P K C \beta$, PKC $\gamma$, Akt, phosphatidylinositide kinase 3 (PI3K), IкB- $\alpha$, phosphorylated IkB- $\alpha$, c-Jun N-terminal kinase (JNK), phosphorylated JNK, p38, phosphorylated p38, extracellular signal-related kinase (ERK), phosphorylated ERK, and $\beta$-actin (Cell Signaling Technology, Beverly, MA, USA). Bound antibodies were detected with peroxidaseconjugated anti-rabbit antibodies followed by chemiluminescence (ECL System; Amersham, Buckinghamshire, UK) and autoradiographic exposure. The intensities of gel bands were calculated with a Gel-Pro Analyzer.

\section{Statistical analysis}

One-way analysis of variance (ANOVA) was used to determine whether mean values differed significantly $(p<0.05)$. If the means were significantly different, a Tukey-Kramer post-hoc multiple group comparison test was used to compare individual groups. Data are shown as mean \pm standard error of the mean (SEM).

\section{Results}

Gen inhibited TPA-induced invasion and migration in human hepatoma cells

In vitro invasion and migration assays, including transwell and wound healing assays, were used to determine the inhibitory effect of Gen on the invasive potency of human hepatoma cell lines (HepG2, Huh-7, and HA22T) 
and murine embryonic liver cells (BNL CL2). To determine whether Gen could inhibit TPA-induced migration on the surface of the tissue culture plate, we performed wound healing experiments. As shown in Figure 1A, migration of
HepG2 cells was increased by TPA incubation and inhibited by $20 \mu \mathrm{M}$ and $40 \mu \mathrm{M}$ of Gen.

HepG2 cells were also treated with TPA and Gen in an invasion chamber to assess the effects of Gen on TPA-

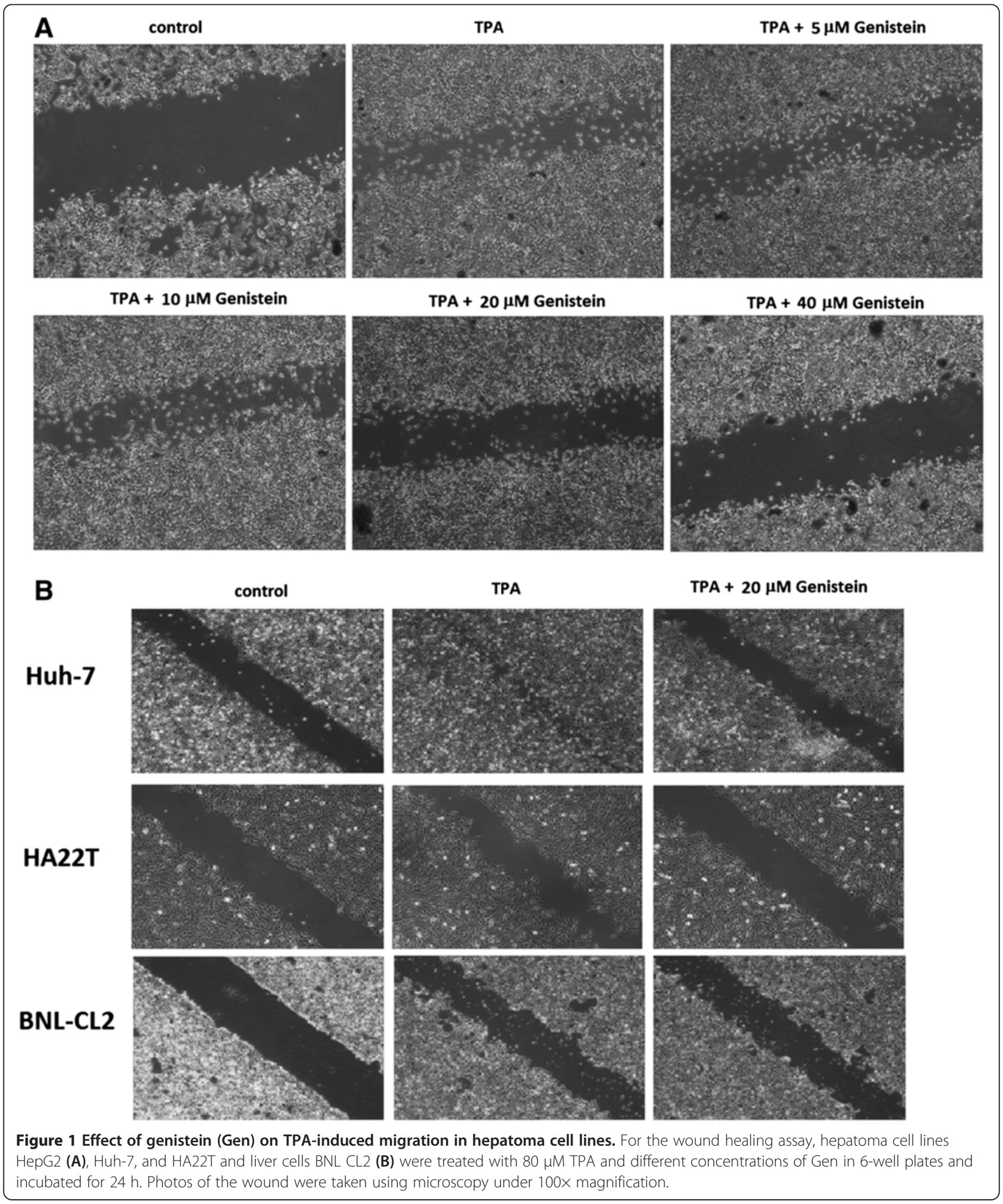




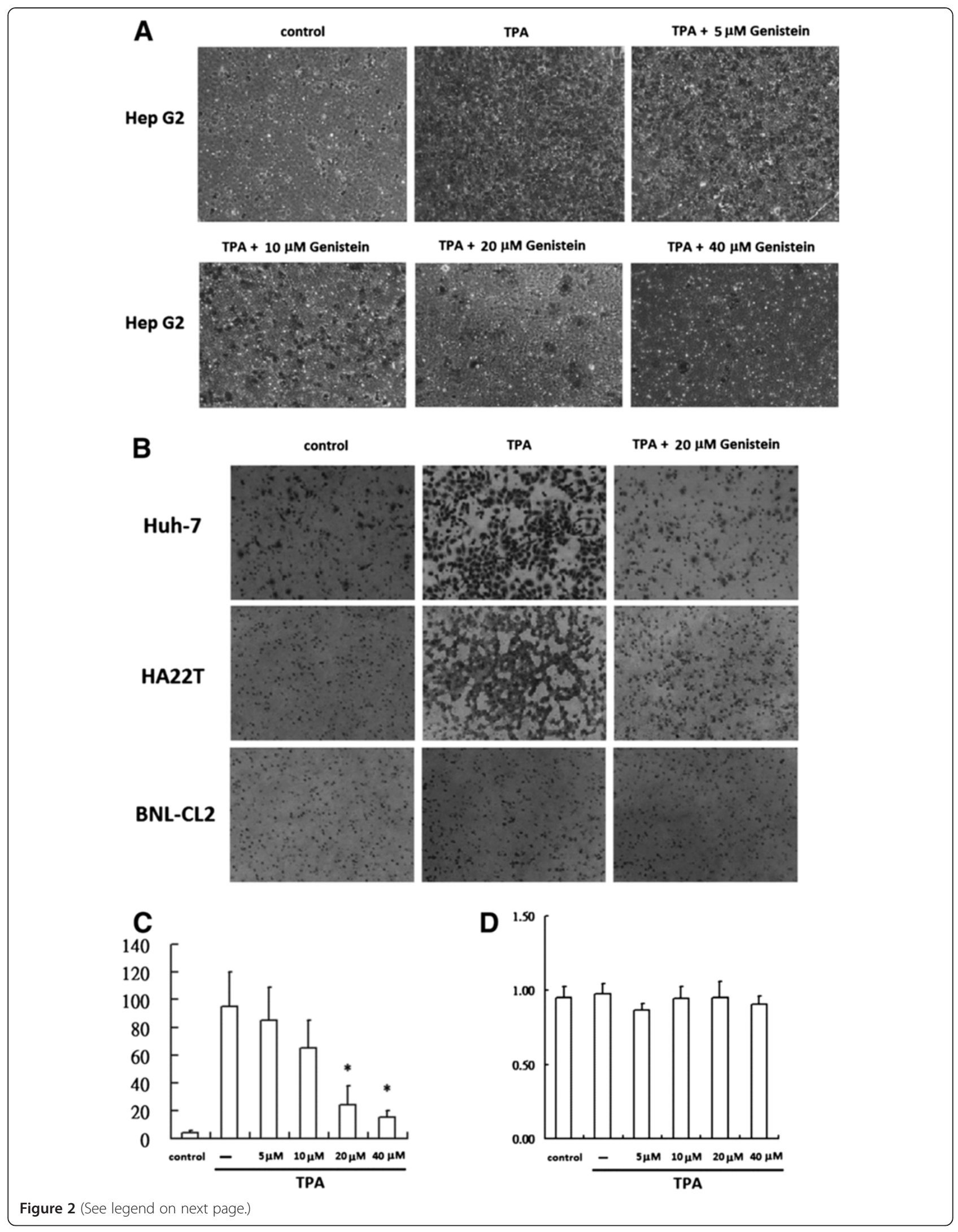


(See figure on previous page.)

Figure 2 Effect of genistein (Gen) on TPA-induced cell invasion. For the invasion assays, hepatoma cell lines HepG2 (A), Huh-7, and HA22T and liver cells BNL CL2 (B) $\left(5 \times 10^{4}\right)$ were resuspended in $200 \mu \mathrm{L}$ of DMEM and added to the upper compartment of Matrigel invasion chambers supplemented with medium and treated with $80 \mu \mathrm{M}$ TPA with or without different concentrations of Gen. After 24-h incubation, the total number of cells on the lower surface of the insert chambers was stained with crystal violet and counted under a microscope (200x magnification). Quantification of cell invasion assay. HepG2 (C), Huh-7, HA22T cells and liver cells BNL CL2 (E) were treated with 5-40 $\mu$ M or $20 \mu \mathrm{M}$ of Gen for 24 h. Cell viability of HepG2 (D), Huh-7, HA22T and BNL CL2 cells (F) was determined by MTT assay. Results are expressed as fold invasion and presented as the total number of invasive cells in treated cells relative to untreated cells. Values represent the mean \pm SEM of 3 independent experiments. ${ }^{*} p<0.01$ compared to TPA-treated cells.

induced cell invasion. We also examined the migration of the other 3 cell lines (Figure 1B). The migration of human hepatoma cell lines (Huh-7 and HA22T) was induced by TPA incubation and inhibited by treatment with Gen at $20 \mu \mathrm{M}$. However, liver cells (BNL CL2) were not affected by TPA incubation and treatment with Gen at $20 \mu \mathrm{M}$.

We calculated the resulting number of invasive cells. The results of TPA-induced cell invasion from the transwell assays are illustrated in Figure 2A and B. TPA induced a $15-20$-fold increase in the number of invasive
HepG2, Huh7, and HA22T cells that migrated through the Matrigel-coated filters. This phenomenon was significantly inhibited by Gen in a concentration-dependent manner in HepG2 cells (Figure 2C). Quantitative data derived from 3 independent experiments showed that Gen effectively inhibited the invasion of HepG2 cells elicited by TPA (Figure 2C). Similar results were obtained in the other human hepatoma cell lines (Huh-7 and HA22T). However, invasion was not effected by TPA incubation and Gen treatment in the BNL CL2 liver cells (Figure 2B). Taken together, these results showed that Gen inhibited

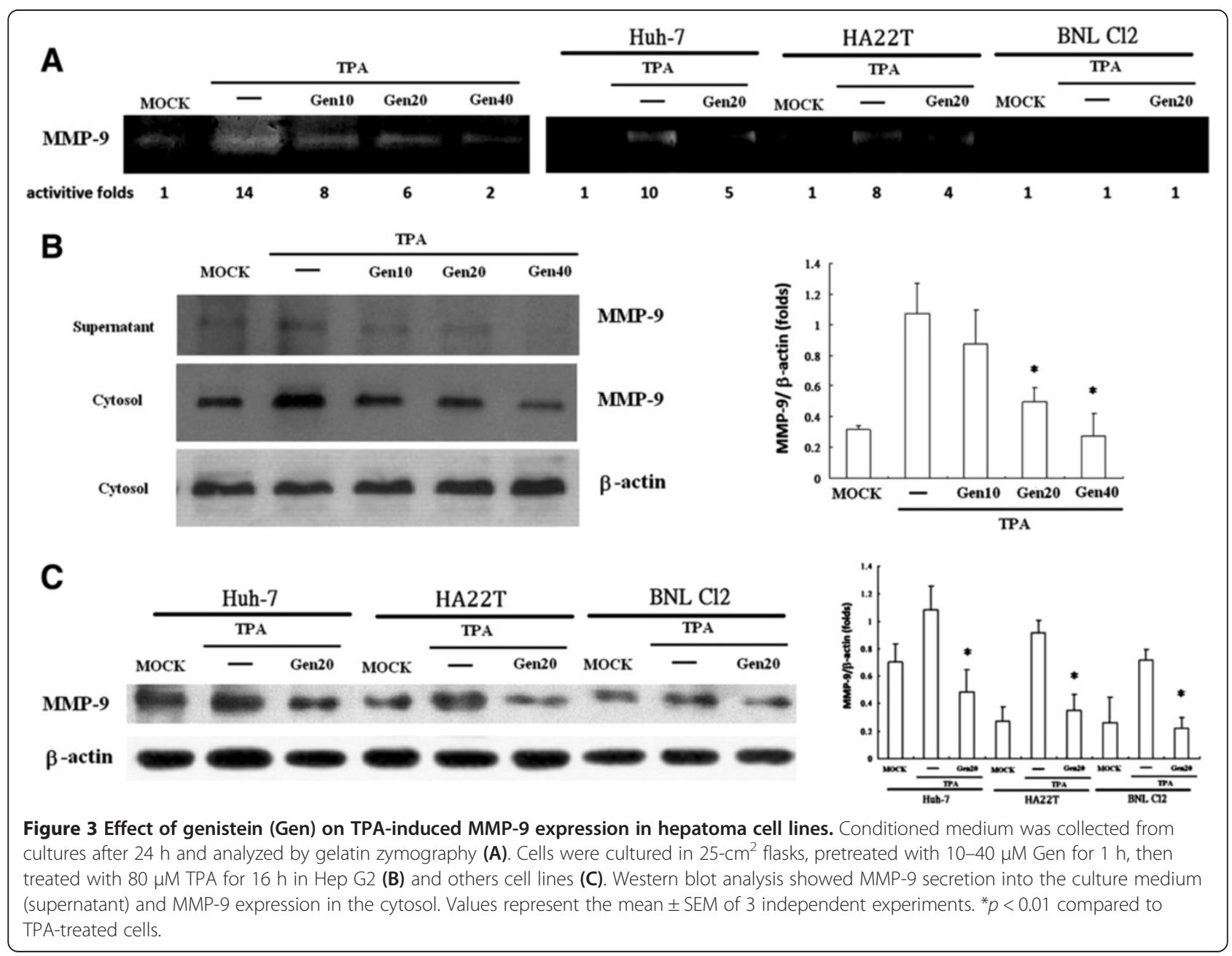


TPA-induced cell motility and transformation, which are essential invasive properties needed for tumor metastasis. As illustrated in Figure 2D, the cytotoxicity of TPA and Gen was evaluated using the MTT assay. No cytotoxic effects were observed for 5-40 $\mu \mathrm{M}$ Gen in HepG2 cells (Figure 2F).

\section{Effect of Gen on TPA-induced MMP-9 expression and activity}

Tumor invasion requires increased expression of MMP-9. To examine whether gelatinolytic MMP activity in hepatoma cells could be activated by TPA, we performed zymographic analysis. Figure 3A shows that treatment with TPA for $24 \mathrm{~h}$ significantly increased MMP-9 expression in hepatoma cell lines (HepG2, Huh-7, and HA22T), which was suppressed by Gen. However, the gelatinolytic activity of MMP was not expressed in murine embryonic liver cells (BNL CL2). Gen-mediated suppression of TPA-induced MMP-9 expression resulted from increased MMP-9 levels in the culture medium (supernatant) and cytosol in a concentration-dependent manner (Figure 3B). In addition, 20- $\mu \mathrm{M}$ Gen-mediated suppression of TPA-induced MMP9 expression resulted from increased MMP-9 concentrations (Figure 3C). Moreover, as shown in Figure 4, Gen dramatically inhibited TPA-induced EGFR expression in Hep G2 cells.

\section{Effect of Gen on TPA-activated transcription of $M M-9, N F-K B$, and $A P-1$ promoters}

To determine whether the transcriptional activities of $M M P-9, N F-\kappa B$, and $A P-1$ are regulated by TPA, we examined the promoter activity of the $N F-\kappa B$ and $A P-1$ genes using luciferase assays. The cells were treated with TPA (with or without Gen) for $16 \mathrm{~h}$, and promoter activity was measured by luciferase assay. Figure $4 \mathrm{~A}$ shows that the $M M P-9$ promoter was increased approximately 4-fold by TPA in HepG2 cells relative to the control MMP-9 promoter-transfected cells, and the activated promoter was suppressed by Gen in a dose-dependent manner and significantly suppressed at concentrations $\geq 10 \mu \mathrm{M}$. Figure $4 \mathrm{~B}$ shows that the $A P-1$ promoter increased approximately 4-fold over the activity in AP-1-transfected cells in response to TPA, which was also inhibited by Gen in a dose-dependent manner and significantly suppressed at concentrations $\geq 10 \mu \mathrm{M}$. As shown in Figure $4 \mathrm{C}$, the $N F-\kappa B$ promoter activity was increased approximately 2.7-fold over that in NF-kB-transfected cells in response to TPA, and this was inhibited by Gen in a

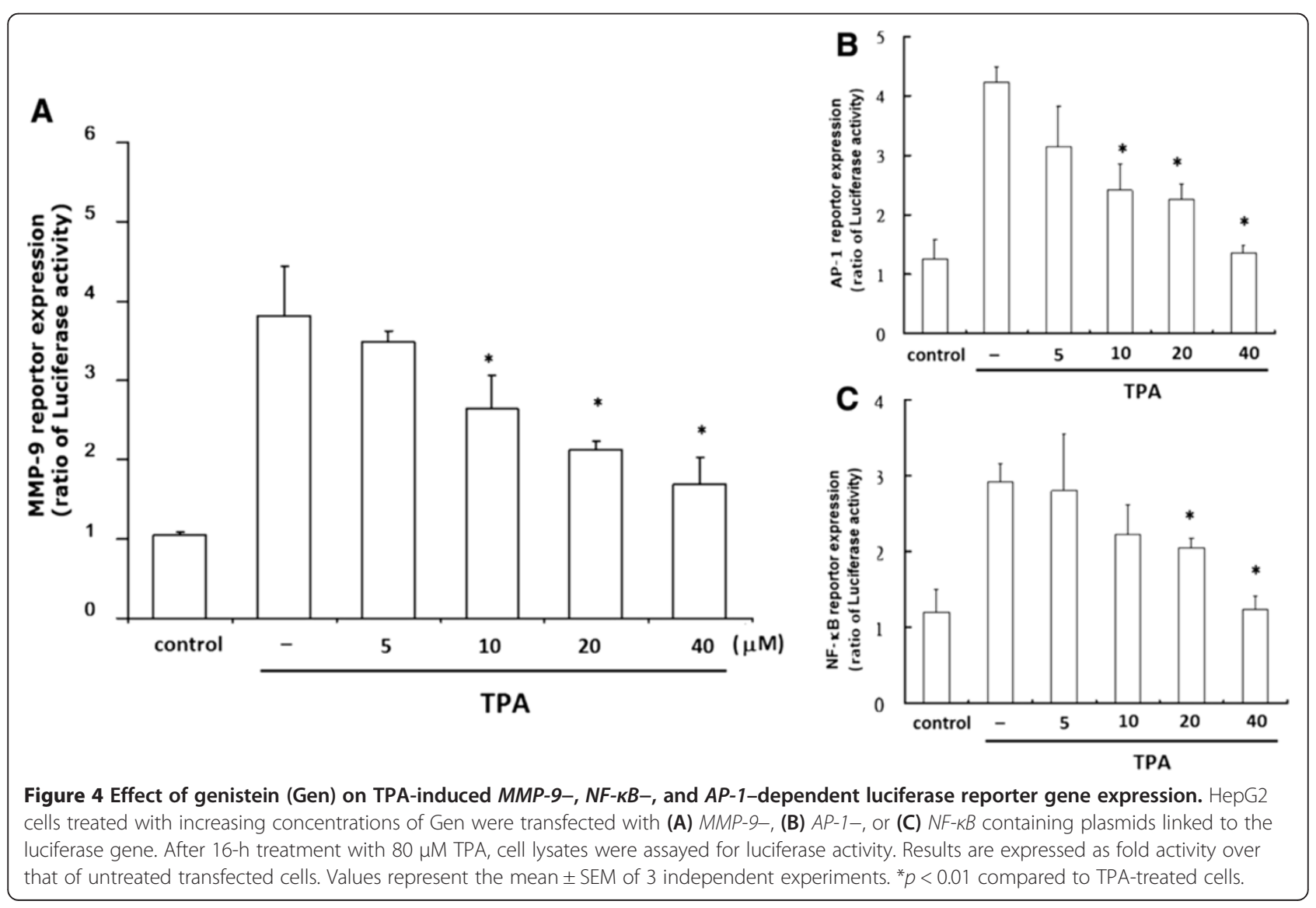




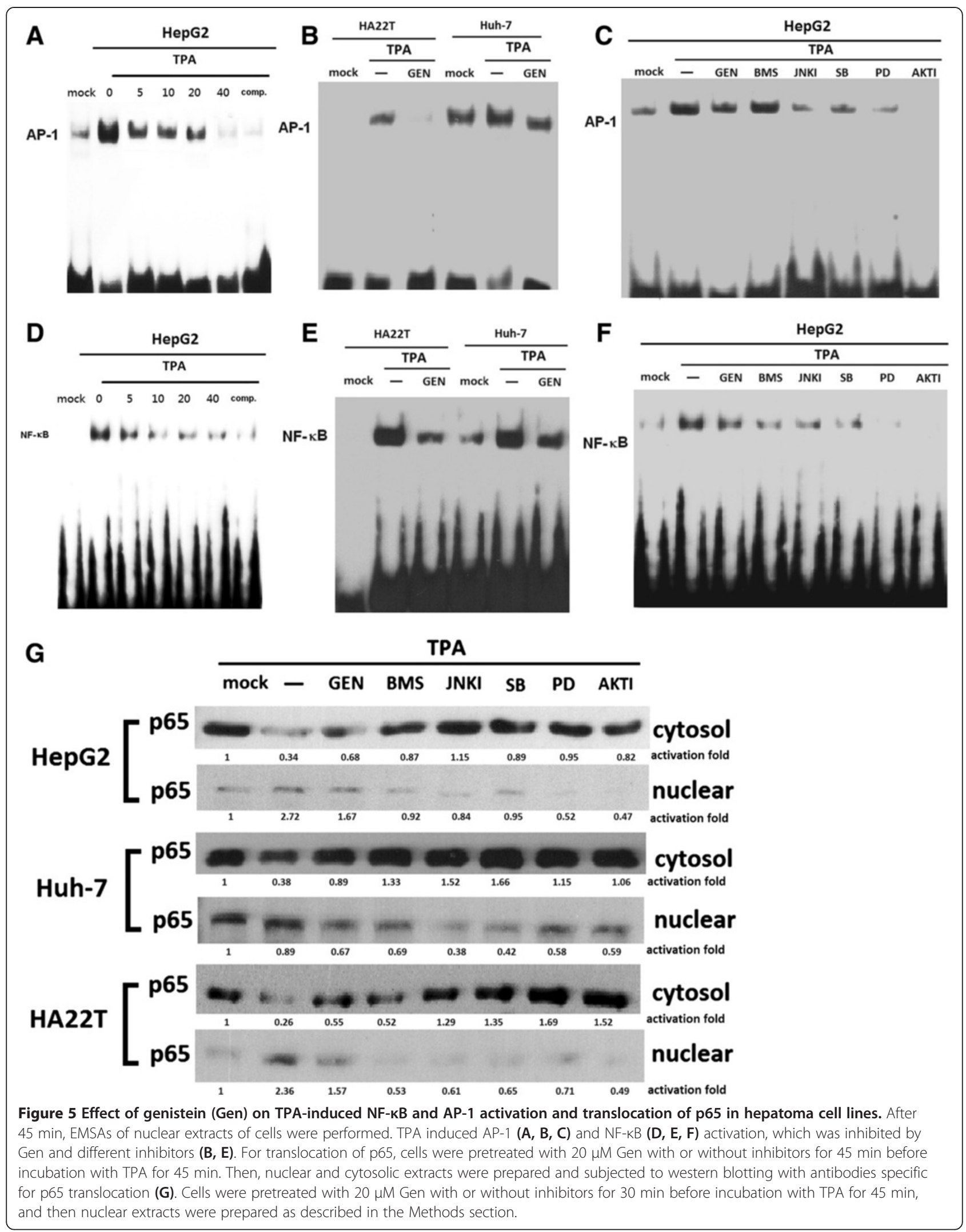




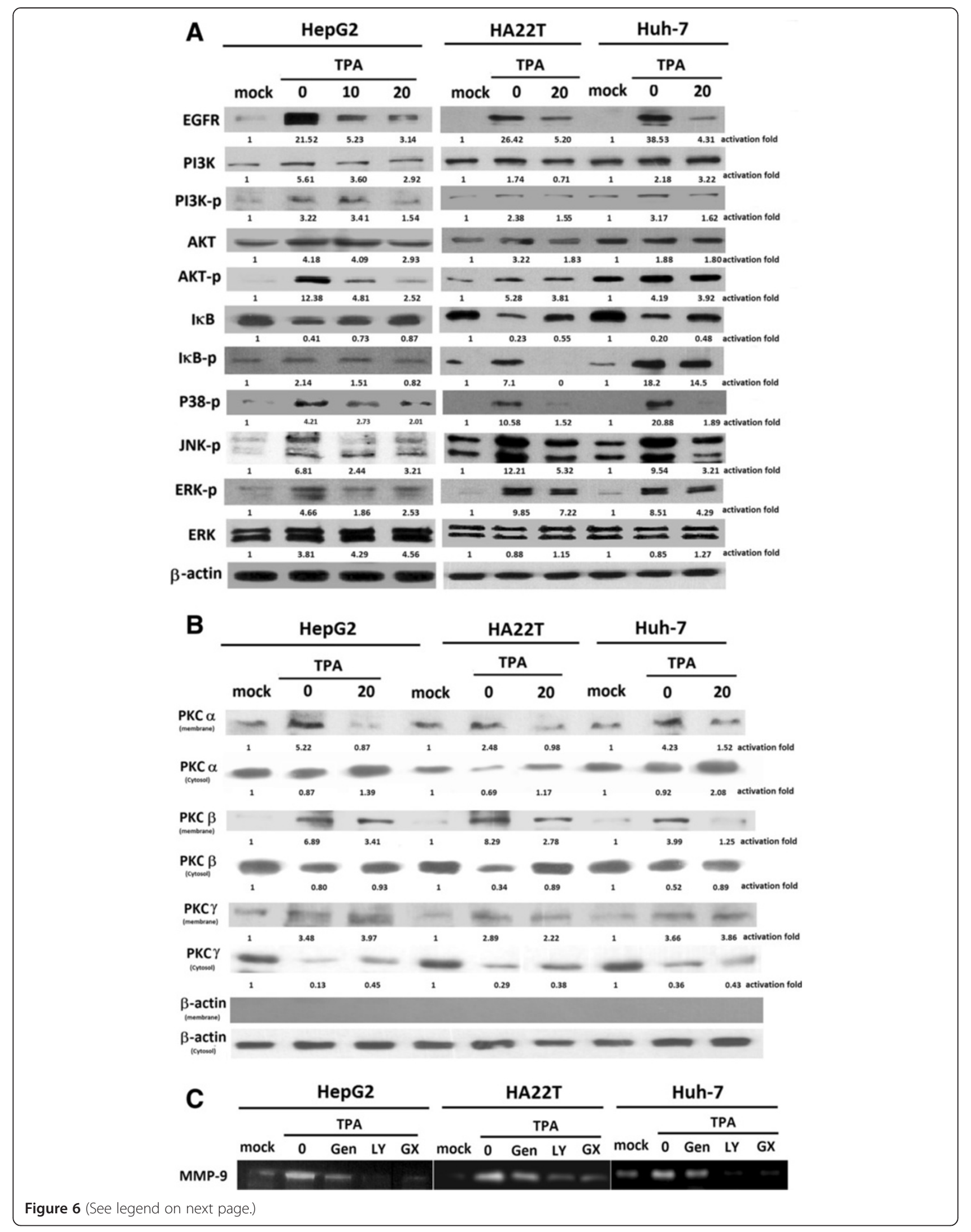


(See figure on previous page.)

Figure 6 Effect of genistein (Gen) on TPA-induced EGFR, MAPK, IKB, AKT, PKC-signaling pathways in hepatoma cell lines. (A) Cells were pretreated with 10 or $20 \mu \mathrm{M}$ Gen for 30 min before incubation with $80 \mu \mathrm{M}$ TPA for 45 min or 24 h (for EGFR), then whole-cell lysates were prepared and subjected to western blotting with antibodies specific for phosphorylated PI3k, AKT, IKB, JNK, p38, and ERK as described in Methods section. (B) HepG2 cells were cultured in serum-free media containing 80 MM TPA for 45 min, then the cell cytosolic and membrane fractions were prepared and then the extracts were analyzed by western blots as described in Methods section. The values under each lane indicate relative density of the band normalized to $\beta$-actin. All analyses were representative of at least three independent experiments. (C) The gelatinolytic activities of MMP-9 were determined by gelatin zymography as described in Materials and Methods.

dose -dependent manner and significantly suppressed at concentrations $\geq 20 \mu \mathrm{M}$.

To determine whether the inhibitory effect of Gen in TPA-treated cells leads to NF- $\mathrm{BB}$ and AP-1 inhibition, the effects of Gen on TPA-stimulated NF-kB- and AP1-specific DNA-protein binding activity were examined. Biotinylated EMSAs showed that TPA increased DNA-binding of NF- $\mathrm{kB}$ and AP-1 after 45 min. Treatment with $20 \mu \mathrm{M}$ Gen inhibited TPA-induced AP-1specific DNA-protein binding (Figure 5A and B), and treatment with $20 \mu \mathrm{M}$ Gen inhibited TPA-induced NF- $\mathrm{kB}$-specific DNA-protein binding compared to TPAinduced cells (Figure 5D and E). We also used specific inhibitors to examine whether TPA-induced DNA-binding of AP-1 and NF-kB. We found that TPA-induced DNAbinding of $A P-1$ was decreased by inhibitors of p38 (SB), JNK (JNKI), ERK (PD), and AKT (AKTI) (Figure 5C). Furthermore DNA-binding of NF- $\mathrm{kB}$ was decreased by inhibitors of IKK (BMS), JNK (JNKI), and AKT (AKTI) in hepatoma cells (Figure 5F). We also used specific inhibitors to examine the translocation of NF- $\mathrm{B}$ p 65 . The translocation was aborted by $20 \mu \mathrm{M}$ Gen and inhibitors of IKK (BMS), JNK (JNKI), and AKT (AKTI) (Figure 5G).

\section{Inhibitory effect of Gen on TPA-induced activation of MAPKs, PI3K, Akt, and PKC}

Mitogen-activated protein kinases (MAPKs) are known to regulate $\mathrm{AP}-1$ and $\mathrm{NF}-\mathrm{kB}$ activation via multiple mechanisms. Studies have shown that the MAPK, IкB, and PI3K/ Akt signaling pathways are involved in TPA-mediated induction of EGFR and MMP-9 [26,27]. We investigated the effects of Gen on TPA-induced phosphorylation of ERK, p38, JNK, IkB, and PI3K/Akt activity in hepatoma cells. Western blot analysis revealed that TPA alone caused a significant increase in the phosphorylation of ERK, p38, JNK, IKB, PI3K, and Akt compared to vehicle-treated controls; this phosphorylation was inhibited by pretreatment with Gen (Figure 6A). Our results showed that the TPAinduced phosphorylation of MAPK, IKB, and PI3K/Akt in cells treated with $20 \mu \mathrm{M}$ Gen was decreased, with the exception of the phosphorylation of p38 and IkB with $20 \mu \mathrm{M}$ Gen. As illustrated in Figure 6, Gen markedly abrogated TPA-induced MMP-9 enzyme activity through inhibition of the MAPK, IкB, and PI3K/Akt signaling pathways.

\section{Discussion}

Epidemiologic studies have demonstrated that the consumption of fruits and vegetables can reduce the risk of several types of human cancers [28]. Approximately $70 \%$ of the drugs used for cancer treatment are derived from or based on natural products [29,30]. A number of phytochemicals can inhibit tumor metastasis and cell invasion via suppression of $M M P$ gene expression and enzymatic activity. For example, curcumin interferes with the activity of MMP-9, reducing degradation of the extracellular matrix, which forms the basis of the angiogenic switch [31]. Hesperidin suppresses TPA-induced MMP-9 transcription by inhibiting NF- $\mathrm{kB}$ activity [32], and pterostilbene inhibits TPA-stimulated $N F-\kappa B$ and $A P-1$ transcriptional activities [27]. Gen is a small, biologically active flavonoid that is abundant in soy. Gen is best known for its ability to inhibit cancer progression and metastasis. Consumption of Gen in the diet has been linked to decreased rates of metastatic cancer in a number of population-based studies [33]. In HCC, Gen has anti-mutagenic activity [34] and induces apoptosis [35]. In the present study, we showed for the first time that Gen suppresses TPA-induced cell invasive activity and MMP-9 expression by reducing tumor migration and invasion of HCC.

Several stimulators increase the expression of MMP-9 via various signaling pathways and result in increased invasiveness in cell lines. Specifically, TPA-induced MMP9 expression has been studied extensively in HCC cells $[14,27,36]$. These studies suggest that TPA-induced MMP9 expression in HepG2 cells occurs by activating phosphorylation of MAPK, IkB, and Akt signaling pathways. These pathways activate the transcription factors NF- $\mathrm{BB}$ and AP-1. We previously reported that NF- $\mathrm{B}$ and AP-1 are activated in TPA-induced MMP-9 expression via IkB and MAPK pathways in HCC cells [14]. Another report showed that NF- $\mathrm{KB}$ and AP-1 were activated following TPA-induced MMP-9 activation though extracellular signal-regulated MAPK and PI3K/Akt [27,37]. The present study showed that Gen effectively suppressed TPAinduced MMP-9 gene expression by suppressing the MAPK/AP-1 and PI3K/AKT/NF-kB cascades, with consequent suppression of tumor migration and invasion of human hepatoma HepG2 cells.

EGFR autocrine/paracrine pathways contribute to a number of processes that are important in the development and 
progression of cancer, including cell proliferation, apoptosis, angiogenesis, and metastatic spread. High expression of EGFR has been observed in numerous human tumors, including lung, colon, breast, head and neck, ovarian, bladder, and liver cancers, and has been shown to correlate with advanced tumor stage and poor clinical prognosis [38-40]. The EGFR signaling pathway is associated with metastatic properties, including cell motility, adhesion, and invasion in vitro [41,42]. EGFR activates intracellular signaling cascades, including Ras/Raf/MEK/ERK and PI3K/Akt, and subsequently controls proliferation, migration, and apoptosis [43]. Activation of NF- $\mathrm{kB}$ and AP-1 is centrally involved in the induction of the MMP-9 gene associated with the invasion and metastasis of tumor cells by different agents, including TPA and growth factors, such as EGF $[27,44,45]$. There is a report that TPA induces EGFR expression in HepG2 cells [27]. Thus, the regulation of NF- $\mathrm{kB}$ and AP-1, downstream of the PI3K/Akt and MAPK pathways, might be involved in Gen suppression of TPA-induced MMP-9 expression and invasion in HepG2 cells.

\section{Conclusion}

In conclusion, we provided evidence that Gen promotes anti-invasive and anti-metastatic effects against TPAmediated metastasis via downregulation of MMP-9 and EGFR and subsequent suppression of NF- $\mathrm{kB}$ and $\mathrm{AP}-1$ transcription factors though inhibition of MAPK, ІкB, and PI3K/Akt signaling pathways. Therefore, we conclude that MMP-9 inhibitory activity of Gen and its inhibition of multiple signal transduction pathways suggest its therapeutic potential for controlling the invasiveness and metastasis of HCC.

\begin{abstract}
Abbreviations
Gen: Genistein; MMP-9: Matrix metalloproteinase-9; HCC: Hepatocellular carcinoma; TPA: 12-O-Tetradecanoylphorbol-13-acetate; AP-1: Activator protein-1; NF-kB: Nuclear factor-KB; JNK: c-Jun N-terminal kinase; PI3K: Phosphoinositide 3-kinases; ERK: Extracellular signal-regulated protein kinase; EMSA: Electrophoretic mobility shift assay; MAPK: Mitogen-activated protein kinase; SB: SB203580 P38 inhibitor; PD: PD98059 MEK/ERK inhibitor; JINK: JNK inhibitor; BMS: IKK inhibitor; AKTI: AKT inhibitor; NE: Nuclear extract.
\end{abstract}

\section{Competing interests}

The authors declare that they have no competing interests.

\author{
Authors' contributions \\ CC Yeh, SD Wang, and ST Kao performed the molecular genetic studies, \\ participated in the sequence alignment, and drafted the manuscript. CC Yeh \\ and SD Wang participated in the design of the study and performed the \\ statistical analysis. CJ Liu, ST Kao, and CC Yeh conceived of the study, \\ participated in its design and coordination, and helped to draft the \\ manuscript. All authors read and approved the final manuscript.
}

\section{Acknowledgements}

This work was supported by grants (NSC98-2320-B-303-002) from the National Science Council and (DTCRD98 [2]-12) from the Buddhist Dalin Tzu Chi General Hospital, Taiwan.

\section{Author details}

${ }^{1}$ School of Post-Baccalaureate Chinese Medicine, Tzu Chi University, Hualien, Taiwan. ${ }^{2}$ Department of Chinese Medicine, Buddhist Dalin Tzu Chi General Hospital, 2 Min-Sheng Road, Dalin Town, Chia-Yi 62247, Taiwan. ${ }^{3}$ School of Chinese Medicine, China Medical University, Taichung, Taiwan. ${ }^{4}$ Division of Chinese Medicine, China Medical University Hospital, Taichung, Taiwan.

${ }^{5}$ School of Post-Baccalaureate Chinese Medicine, Collage of Chinese Medicine, China Medical University, Taichung, Taiwan.

Received: 26 February 2013 Accepted: 15 January 2014

Published: 16 January 2014

\section{References}

1. Schmitz HC, Weishaupt D, Borel N, Padberg B, Bfirki K: The use of ultrasound and computed tomography for the diagnosis of a squamous cell carcinoma of the oesophago-cardial region of the stomach in a rhesus monkey. Lab Anim 2004, 38(1):92-97.

2. Jemal A, Bray F, Center MM, Ferlay J, Ward E, Forman D: Global cancer statistics. CA Cancer J Clin 2011, 61(2):69-90.

3. Farazi PA, DePinho RA: Hepatocellular carcinoma pathogenesis: from genes to environment. Nat Rev Cancer 2006, 6(9):674-687.

4. Monvoisin A, Neaud V, De Ledinghen V, Dubuisson L, Balabaud C, Bioulac-Sage P, Desmouliere A, Rosenbaum J: Direct evidence that hepatocyte growth factor-induced invasion of hepatocellular carcinoma cells is mediated by urokinase. J Hepatol 1999, 30(3):511-518.

5. Stamenkovic I: Matrix metalloproteinases in tumor invasion and metastasis. Semin Cancer Biol 2000, 10(6):415-433.

6. Torzilli PA, Bourne JW, Cigler T, Vincent $C T$ : A new paradigm for mechanobiological mechanisms in tumor metastasis. Semin Cancer Biol 2012, 22(5-6):385-395.

7. Arii S, Mise M, Harada T, Furutani M, Ishigami S, Niwano M, Mizumoto M, Fukumoto M, Imamura M: Overexpression of matrix metalloproteinase 9 gene in hepatocellular carcinoma with invasive potential. Hepatology 1996, 24(2):316-322.

8. Sato H, Seiki M: Regulatory mechanism of $92 \mathrm{kDa}$ type IV collagenase gene expression which is associated with invasiveness of tumor cells. Oncogene 1993, 8(2):395-405.

9. Lee EJ, Kim DI, Kim WJ, Moon SK: Naringin inhibits matrix metalloproteinase-9 expression and AKT phosphorylation in tumor necrosis factor-alpha-induced vascular smooth muscle cells. Mol Nutr Food Res 2009, 53(12):1582-1591.

10. Freise C, Ruehl M, Erben U, Neumann U, Seehofer D, Kim KY, Trowitzsch-Kienast W, Stroh T, Zeitz M, Somasundaram R: A hepatoprotective Lindera obtusiloba extract suppresses growth and attenuates insulin like growth factor-1 receptor signaling and NF-kappaB activity in human liver cancer cell lines. BMC Complement Altern Med 2011, 11:39.

11. Furstenberger G, Berry DL, Sorg B, Marks F: Skin tumor promotion by phorbol esters is a two-stage process. Proc Natl Acad Sci U S A 1981 78(12):7722-7726.

12. Barry OP, Kazanietz MG: Protein kinase $C$ isozymes, novel phorbol ester receptors and cancer chemotherapy. Curr Pharm Des 2001, 7(17):1725-1744.

13. Liu JF, Crepin M, Liu JM, Barritault D, Ledoux D: FGF-2 and TPA induce matrix metalloproteinase-9 secretion in MCF-7 cells through PKC activation of the Ras/ERK pathway. Biochem Biophys Res Commun 2002, 293(4):1174-1182.

14. Lee KH, Yeh MH, Kao ST, Hung CM, Liu CJ, Huang YY, Yeh CC: The inhibitory effect of hesperidin on tumor cell invasiveness occurs via suppression of activator protein 1 and nuclear factor-kappaB in human hepatocellular carcinoma cells. Toxicol Lett 2010, 194(1-2):42-49.

15. Tategu M, Arauchi $T$, Tanaka $R$, Nakagawa $H$, Yoshida $K$ : Puma is a novel target of soy isoflavone genistein but is dispensable for genisteininduced cell fate determination. Mol Nutr Food Res 2008, 52(4):439-446.

16. Gu Y, Zhu CF, Iwamoto H, Chen JS: Genistein inhibits invasive potential of human hepatocellular carcinoma by altering cell cycle, apoptosis, and angiogenesis. World J Gastroenterol 2005, 11(41):6512-6517.

17. Cui HB, Na XL, Song DF, Liu Y: Blocking effects of genistein on cell proliferation and possible mechanism in human gastric carcinoma. World J Gastroenterol 2005, 11(1):69-72.

18. Qi W, Weber CR, Wasland K, Savkovic SD: Genistein inhibits proliferation of colon cancer cells by attenuating a negative effect of epidermal growth factor on tumor suppressor FOXO3 activity. BMC Cancer 2011, 11:219. 
19. Chiyomaru T, Yamamura S, Zaman MS, Majid S, Deng G, Shahryari V, Saini S, Hirata H, Ueno K, Chang I, Tanaka Y, Tabatabai ZL, Enokida H, Nakagawa M, Dahiya R: Genistein suppresses prostate cancer growth through inhibition of oncogenic MicroRNA-151. PLoS One 2012, 7(8):e43812.

20. Park OJ, Surh Y-J: Chemopreventive potential of epigallocatechin gallate and genistein: evidence from epidemiological and laboratory studies. Toxicol Lett 2004, 150(1):43-56.

21. Jerome-Morais A, Diamond AM, Wright ME: Dietary supplements and human health: for better or for worse? Mol Nutr Food Res 2011, 55(1):122-135.

22. Gu Y, Zhu CF, Dai YL, Zhong Q, Sun B: Inhibitory effects of genistein on metastasis of human hepatocellular carcinoma. World J Gastroenterol 2009, 15(39):4952-4957.

23. Ricote M, Li AC, Willson TM, Kelly CJ, Glass CK: The peroxisome proliferator-activated receptor-gamma is a negative regulator of macrophage activation. Nature 1998, 391(6662):79-82.

24. Yeh CC, Lin CC, Wang SD, Hung CM, Yeh MH, Liu CJ, Kao ST: Protective and immunomodulatory effect of Gingyo-san in a murine model of acute lung inflammation. J Ethnopharmacol 2007, 111(2):418-426.

25. Mullin JM, Soler AP, Laughlin KV, Kampherstein JA, Russo LM, Saladik DT, George K, Shurina RD, O'Brien TG: Chronic exposure of LLC-PK1 epithelia to the phorbol ester TPA produces polyp-like foci with leaky tight junctions and altered protein kinase $\mathrm{C}$-alpha expression and localization. Exp Cell Res 1996, 227(1):12-22.

26. Kajanne $R$, Miettinen $P$, Mehlem A, Leivonen SK, Birrer M, Foschi M, Kahari VM, Leppa S: EGF-R regulates MMP function in fibroblasts through MAPK and AP-1 pathways. J Cell Physiol 2007, 212(2):489-497.

27. Pan MH, Chiou YS, Chen WJ, Wang JM, Badmaev V, Ho CT: Pterostilbene inhibited tumor invasion via suppressing multiple signal transduction pathways in human hepatocellular carcinoma cells. Carcinogenesis 2009, 30(7):1234-1242

28. Pan $\mathrm{MH}, \mathrm{Ho} \mathrm{CT}$ : Chemopreventive effects of natural dietary compounds on cancer development. Chem Soc Rev 2008, 37(11):2558-2574.

29. Newman DJ, Cragg GM, Holbeck S, Sausville EA: Natural products and derivatives as leads to cell cycle pathway targets in cancer chemotherapy. Curr Cancer Drug Targets 2002, 2(4):279-308

30. Yeh CC, Yang JI, Lee JC, Tseng CN, Chan YC, Hseu YC, Tang JY, Chuang LY, Huang HW, Chang FR, Chang HW: Anti-proliferative effect of methanolic extract of Gracilaria tenuistipitata on oral cancer cells involves apoptosis, DNA damage, and oxidative stress. BMC Complement Altern Med 2012, $12: 142$.

31. Chen LX, He YJ, Zhao SZ, Wu JG, Wang JT, Zhu LM, Lin TT, Sun BC, Li XR: Inhibition of tumor growth and vasculogenic mimicry by curcumin through down-regulation of the EphA2/PI3K/MMP pathway in a murine choroidal melanoma model. Cancer Biol Ther 2011, 11(2):229-235.

32. Yeh MH, Kao ST, Hung CM, Liu CJ, Lee KH, Yeh CC: Hesperidin inhibited acetaldehyde-induced matrix metalloproteinase- 9 gene expression in human hepatocellular carcinoma cells. Toxicol Lett 2009, 184(3):204-210.

33. Pavese JM, Farmer RL, Bergan RC: Inhibition of cancer cell invasion and metastasis by genistein. Cancer Metastasis Rev 2010, 29(3):465-482.

34. Lepri SR, Luiz RC, Zanelatto LC, da Silva PB, Sartori D, Ribeiro LR, Mantovani MS: Chemoprotective activity of the isoflavones, genistein and daidzein on mutagenicity induced by direct and indirect mutagens in cultured HTC cells. Cytotechnology 2013, 65(2):213-222.

35. Fang SC, Hsu CL, Lin HT, Yen GC: Anticancer effects of flavonoid derivatives isolated from Millettia reticulata Benth in SK-Hep-1 human hepatocellular carcinoma cells. J Agric Food Chem 2010, 58(2):814-820.

36. Hah N, Lee ST: An absolute role of the PKC-dependent NF-kappaB activation for induction of MMP-9 in hepatocellular carcinoma cells. Biochem Biophys Res Commun 2003, 305(2):428-433.

37. Chien YC, Sheu MJ, Wu CH, Lin WH, Chen YY, Cheng PL, Cheng HC: A Chinese herbal formula "Gan-Lu-Yin" suppresses vascular smooth muscle cell migration by inhibiting matrix metalloproteinase-2/9 through the PI3K/AKT and ERK signaling pathways. BMC Complement Altern Med 2012 $12: 137$.

38. Ito $Y$, Takeda T, Sakon M, Tsujimoto M, Higashiyama S, Noda K, Miyoshi E, Monden M, Matsuura N: Expression and clinical significance of erb-B receptor family in hepatocellular carcinoma. Br J Cancer 2001, 84(10):1377-1383.

39. Abbaoui B, Riedl KM, Ralston RA, Thomas-Ahner JM, Schwartz SJ, Clinton SK, Mortazavi A: Inhibition of bladder cancer by broccoli isothiocyanates sulforaphane and erucin: characterization, metabolism, and interconversion. Mol Nutr Food Res 2012, 56(11):1675-1687.

40. Qiu P, Guan H, Dong P, Guo S, Zheng J, Li S, Chen Y, Ho CT, Pan MH, McClements DJ, Xiao H: The inhibitory effects of 5-hydroxy-3,6,7,8,3',4'hexamethoxyflavone on human colon cancer cells. Mol Nutr Food Res 2011, 55(10):1523-1532.

41. Woodburn JR: The epidermal growth factor receptor and its inhibition in cancer therapy. Pharmacol Ther 1999, 82(2-3):241-250.

42. Sun Q, Prasad R, Rosenthal E, Katiyar SK: Grape seed proanthocyanidins inhibit the invasive potential of head and neck cutaneous squamous cell carcinoma cells by targeting EGFR expression and epithelial-tomesenchymal transition. BMC Complement Altern Med 2011, 11:134

43. Hwang MK, Bode AM, Byun S, Song NR, Lee HJ, Lee KW, Dong Z: Cocarcinogenic effect of capsaicin involves activation of EGFR signaling but not TRPV1. Cancer Res 2010, 70(17):6859-6869.

44. Ueno Y, Sakurai H, Matsuo M, Choo MK, Koizumi K, Saiki I: Selective inhibition of TNF-alpha-induced activation of mitogen-activated protein kinases and metastatic activities by gefitinib. Br J Cancer 2005 92(9):1690-1695.

45. Hwang YP, Yun HJ, Choi JH, Han EH, Kim HG, Song GY, Kwon Kl, Jeong TC, Jeong HG: Suppression of EGF-induced tumor cell migration and matrix metalloproteinase- 9 expression by capsaicin via the inhibition of EGFR-mediated FAK/Akt, PKC/Raf/ERK, p38 MAPK, and AP-1 signaling. Mol Nutr Food Res 2011, 55(4):594-605.

doi:10.1186/1472-6882-14-26

Cite this article as: Wang et al:: Genistein inhibits tumor invasion by suppressing multiple signal transduction pathways in human hepatocellular carcinoma cells. BMC Complementary and Alternative Medicine 2014 14:26.

\section{Submit your next manuscript to BioMed Central and take full advantage of:}

- Convenient online submission

- Thorough peer review

- No space constraints or color figure charges

- Immediate publication on acceptance

- Inclusion in PubMed, CAS, Scopus and Google Scholar

- Research which is freely available for redistribution 